\title{
Generalist or Specialist? The Skills of CEO and Director That Really Matter to Firm Performance
}

\author{
Muhammad Saiful Hakim ${ }^{1,2}$, Chih Liang Liu ${ }^{1}$ \\ ${ }^{1}$ Department of Finance, National Yunlin University of Science and Technology, Taiwan \\ ${ }^{2}$ Department of Business Management, Institut Teknologi Sepuluh Nopember, Surabaya \\ Email: ms_hakim@mb.its.ac.id
}

How to cite this paper: Hakim, M. S., \& Liu, C. L. (2021). Generalist or Specialist? The Skills of CEO and Director That Really Matter to Firm Performance. Modern Economy, 12, 1768-1781.

https://doi.org/10.4236/me.2021.1212090

Received: November 1, 2021

Accepted: December 7, 2021

Published: December 10, 2021

Copyright $\odot 2021$ by author(s) and Scientific Research Publishing Inc. This work is licensed under the Creative Commons Attribution International License (CC BY 4.0).

http://creativecommons.org/licenses/by/4.0/

\begin{abstract}
The policy reforms on disclosure of individual skills and the increasing number of studies focusing on individual attributes of CEOs and directors have motivated research exploring the skill of directors. In this study, we are examining the benefit of director skill and firm performance. This study answers whether the skill generality or skill specialty is beneficial to the firm. We employ the multidimensional category of skill variable for director and CEO on the Taiwan stock market. The empirical result shows that executives and board members with higher educational backgrounds, expertise, and experiences contribute to higher firm performance and lower firm risks. Furthermore, we also find that generalist skill in directors is associated with better firm performance and firm risk.
\end{abstract}

\section{Keywords}

Skill, Firm Performance, CEO, Board of Directors

\section{Introduction}

Recent literature addresses the increasing importance of the individual skills of CEOs and board directors. Several studies indicate that generalist director is positively associated with corporate outcomes ${ }^{1}$, whereas other research reports that skill specialty is crucial ${ }^{2}$. Thus, the question of whether the skill set relates to ${ }^{1}$ See Bertrand and Schoar (2003), Adams, Almeida, and Ferreira (2005), Lazear (2012), Giannetti (2011), White, Woidtke, Black, and Schweitzer (2014), Custódio, Ferreira, and Matos (2013), and Tate and Yang (2015).

${ }^{2}$ See Fahlenbrach, Minton, and Pan (2011), and Mobbs \& Raheja (2012), and Mobbs (2013). 
corporate outcomes remains still controversial. This research helps resolve this controversy and contributes to this line of literature by examining the impact of generalists' or specialists' skills on firm performance and risk.

Inconsistent findings in current skill literature leave the unanswered question of whether individual skills contribute value to companies. Fich (2005); Drobetz, Von Meyerinck, Oesch, and Schmid (2018), Dass, Kini, Nanda, Onal, and Wang (2014), Faleye et al. (2017), Landier, Sauvagnat, Sraer, and Thesmar (2013) and Kim and $\mathrm{Lu}$ (2017) find that the experiences of CEOs and directors make an important difference to firm value and corporate outcomes. However, Fahlenbrach, Low, and Stulz (2010) and Kang, Kim, and Lu (2018) find that experience has an insignificant effect on value creation. These recent studies emphasize two types of managerial human capital: skill generality, defined as a skill that is not specific to any organization and is transferable across firms, and skill specialty, defined as firm-specific human capital valuable only within an organization.

Furthermore, the question of whether the CEOs'/directors' skill generality or specialty results in better corporate outcomes is increasingly important. Financial economists acknowledge the influence of individual-specific attributes and characteristics on corporate outcomes (Hambrick \& Mason, 1984). Bertrand and Schoar (2003) and Graham, Li, and Qiu (2012) note that executives' fixed effects are important determinants in corporate decision-making, and Akyol and Verwijmeren (2013) argue that directors are not one dimensional. Kaplan and Klebanov (2012) and Custódio et al. (2013) use factor analysis to extract different dimensions of directors' skills to examine commonalities in CEO characteristics. They find that some firms appoint directors with different skills to their board, whereas others focus on the same kills. Falato, Li, and Milbourn (2010) report differences in CEOs' skills and find the distinction in their compensation arrangements. In addition, Li \& Patel (2019) suggest that firm generalist is associated with a lower level of performance, especially for CEO in longer tenure. Inspired by these works, this study examines how the generalist or specialist CEOs' /directors' individual skills impact corporate outcomes.

Using 2006-2014 data and proxy statements of Taiwan listed non-financial firms, this research decomposes $\mathrm{CEO}$ and director individual skills into three dimensions-education background, professional expertise, and prior experience-to answer the questions: Are CEOs/directors with higher education, greater professional expertise, more prior experiences, or greater skill generality associated with better corporate performance and reduced risks. Our empirical findings show that executives and board members with higher educational backgrounds and greater expertise and experiences contribute to higher performance and lower risks. In addition, skill generality is helpful to increase firm performance and reduce firm risk.

This research provides a comprehensive data set of CEO/director skills: manager education background, professional expertise, and prior experience. Because individual characteristics and abilities are multidimensional and hard to observe, and previous theoretical and empirical studies do not specifically indi- 
cate which characteristics are more important for corporate governance, this empirical study focuses on the most critical manifest criterion skills. An increasing number of studies focus on different skills criteria, including education background, professional expertise, and prior experience. However, few studies consider all the skills in combination. This study, therefore, complements previous studies by including various individual skills to provide a comprehensive examination of the roles of different skills to firm performance.

Second, this research helps to examine the debate over the value of generalists versus specialists as CEOs/directors. The crucial question of whether skill generalists or skill specialists are beneficial to business is still controversial (Murphy, Zabojnik, \& Zábojník, 2006; Lazear, 2012; Custódio \& Metzger, 2013; Custódio, Ferreira, \& Matos, 2013; Martijn Cremers \& Grinstein, 2014; Li \& Patel, 2019). Therefore, this research provides an empirical test in comparing the two sets of director skills.

The remaining part of the paper proceeds as follows: Section 2 outlines develop the hypotheses. Then, Section 3 describes the data and research design. Finally, Section 4 presents the results, and Section 5 concludes.

\section{Hypothesis Formulation}

CEOs and directors provide several benefits. Faleye et al. (2017) argue that specialized expertise is the most important qualification that directors bring to the boardroom. Specialist CEOs bring firm-specific knowledge, which is an essential dimension of the CEO's skill set. Internal candidates for CEO have more firm-specific knowledge than external candidates (Groysberg, McLean, \& Nohria, 2006). For example, Mobbs and Raheja (2012) and Mobbs (2013) find that insiders with specific talent are valuable resources to their boards to force CEO turnover sensitivity and to improve accounting performance. In addition, Custódio et al. (2013) reports that specialist CEOs can encourage and promote other skilled specialists to invest in innovation and to identify good projects. Fahlenbrach et al. (2011) note that the former CEO's specific knowledge can help the board overcome some of the difficulties in evaluating the current CEO's performance and increase performance-turnover sensitivity.

This line of research also indicates that specialists have potential drawbacks. Internal candidates for $\mathrm{CEO}$ usually do not hold a top position at the corporation and therefore may lack leadership skills (Groysberg, McLean, \& Nohria, 2006). In addition, Brockman, Lee, and Salas (2012) find that CEOs with more in-house experience receive lower total compensation arrangements, higher cash payment, fewer performance-based incentives, and lower wealth-risk sensitivities.

Some related literature argues that generalist CEOs and directors provide benefits to the firm. For example, generalist executives are better at thinking outside the box to take advantage of knowledge beyond the current technological domain (Custódio, Ferreira, \& Matos, 2013). Lazear (2012) develops a theory that firms weigh various skills differently and finds that diversified firms usually 
need across-industries experiences. Tate and Yang (2015) show that individuals leaving diversified firms have better outcomes in the labour market. Also, Custódio and Metzger (2013) note that generalist CEOs spur innovation because they have different skills that can be easily applied elsewhere.

Although the literature shows that both generalists and specialists can be beneficial to companies in different ways, extant empirical results are inconsistent and the question of whether $\mathrm{CEO} /$ director skill generality or specialty is more helpful to the firm and its board is still controversial. From the perspective of the nominating and appointing process, Murphy and Zabojnik (2006) argue that general managerial skills have become more important than firm-specific skills. Generalists can acquire higher compensation rents as skills can be applied elsewhere, thereby reducing specialists' bargaining power in labor market. Custódio et al. (2013) indicate that outside hires are more likely than internal promotions because the benefit of a better match between an outside-appointed generalist $\mathrm{CEO}$ and the firm outweighs the cost of a lack of internal firm-specific capital. Custódio et al. (2013) find that the CEO pay premium increases 19\% when firms appoint an external $\mathrm{CO}$ and switch from a specialist to a generalist because, compared to specialist CEOs, generalist CEOs bring broader benefits from the outside that can foster innovation.

From the perspective of skill generality and specialty, Adams et al. (2005) show that outside directors have 2.7 skills, compared to 2.2 skills for inside directors. This extra skill could provide the firm with more perspective on tools to improve business. Moreover, Custódio et al. (2013) find that CEOs with more general managerial skills and experiences are more likely to exploit innovative projects, invest more in research and development ( $\& R \& D)$, and produce more patents. They also find that generalists with more diverse business experiences are less sensitive to termination risk compared to CEOs with focused professional experience. Manso (2011) and Almeida, Hsu, and Li (2013) show that generalist CEOs engage more in exploratory strategies that involve higher risk-taking in searching for new technologies than exploitative strategies that refine existing technologies.

Another argument suggests that generalist CEOs are not necessarily the best match for every firm and that specialists help to create better performance because complex business operations require more specific advice and greater expertise. Thus, Companies with a greater need for firm-specific knowledge will require large boards (Coles, Daniel, \& Naveen, 2008). Dah et al. (2014) suggest that costs are associated with transforming generalists' knowledge and experience to firms as they lack firm-specific information. Adams et al. (2005) find that skills variety does not improve firm performance, suggesting that directors with a skill-concentrated background benefit firm performance.

Thus, we posit that, relative to director with specialist skill, generalist director is more beneficial to corporate outcomes.

Hypothesis. Generalists CEOs and board directors help to create better corporate performance and reduce risk. 


\section{Research Method}

\subsection{Data}

Data were collected from the Taiwan-listed non-financial firms from 2006 to 2014. The period is selected because the 2006 regulation requires Taiwan-listed firms to disclose each executive and director's experience, qualifications, attributes, or skills. However, in 2014 the regulation was abolished. Therefore, the period of disclosure policy reforms provides a unique and comprehensive data set to explore the properties of directors' skills and background characteristics. The detailed data on individual skills of directors and executives were extracted from the Taiwan Economic Journal (TEJ) database. The firm financial figures are also obtained from the same database.

\subsection{Measurement}

\subsubsection{Skill}

In the stream of research director characteristics, scholars have underlined the critical point in investigating skill not as a single dimension variable but more on a multidimensional set of capabilities (Adams, Akyol, \& Verwijmeren, 2018). Therefore, our measurement on $\mathrm{CEO} /$ director skills variable is scored based on multidimensional set specifically: Education (EDU) is the sum of all dimensions of education background is scored from zero (lowest educational background) to 3 (highest educational background; Professional expertise (PRO) is the sum of all dimensions of professional expertise is scored from zero (less professional expertise) to 13 (most professional expertise); Experience (EXP) is the sum of all dimensions of experience expertise is scored from zero (fewest prior experiences) to 9 (most prior experiences), skill generality (GNR) is the skill general$i t y$, measured by the first factor of the principal components analysis of the three dimensions of skills, including EDU, PRO, and EXP. A lower (higher) index score indicates that the $\mathrm{CEO} /$ director is a specialist (generalist).

The detail of each subskill included in the variable is listed in Table A1 in the Appendix

\subsubsection{Firm Performance and Risk}

In this study, we employ firm performance and firm risk as our response variable. Firm performance variable in this study is measured by variable of ROE that is the ratio of net income to total assets; and EPS which is earnings per share. Next variable is we utilize firm risk with proxies of ZSCR is z-score, calculated by the formula: $\mathrm{z}$-score $=1.2^{\star}($ working capital/total assets $)+1.4^{\star}($ retained earnings/total assets $)+3.3^{*}$ (earnings before interest and taxes/total assets) + $0.6^{*}$ (market value of equity/total liabilities) $+0.99^{*}$ (sales/total assets); and $\sigma$ $(R O E)$ is the standard deviation of $R O E$ in last 12 quarters. In this study, we also include several control variables. The detail of measurement for the control variables is listed in Table A1 in the Appendix. Table 1 provides descriptive statistics of the variables used in this research. 
Table 1. Descriptive summaries.

\begin{tabular}{|c|c|c|c|c|c|}
\hline & & Mean & Std. Dev. & Min & Max \\
\hline ROE & (1) & 1.48 & 0.76 & -2.71 & 5.37 \\
\hline EPS & (2) & 1.66 & 0.86 & -2.80 & 18.60 \\
\hline ZSCR & (3) & 0.65 & 0.39 & 0.02 & 4.03 \\
\hline$\sigma(R O E)$ & (4) & 0.16 & 0.37 & 0.00 & 1.00 \\
\hline fsize & (5) & 22.81 & 1.49 & 18.86 & 28.53 \\
\hline lvrg & (6) & 0.50 & 0.13 & 0.03 & 0.98 \\
\hline $\mathrm{mbr}$ & (7) & 0.66 & 0.52 & 0.04 & 10.54 \\
\hline tgbl & (8) & 0.31 & 0.18 & 0.00 & 0.95 \\
\hline prft & (9) & 0.02 & 0.04 & -2.77 & 0.84 \\
\hline bsize & (10) & 7.06 & 2.16 & 3.00 & 20.00 \\
\hline dual & (11) & 0.46 & 0.49 & 0.00 & 1.00 \\
\hline indp & (12) & 0.16 & 0.19 & 0.00 & 1.00 \\
\hline inst & (13) & 0.38 & 0.22 & 0.00 & 1.00 \\
\hline mngr & (14) & 0.01 & 0.02 & 0.00 & 0.28 \\
\hline blck & (15) & 0.22 & 0.11 & 0.00 & 0.79 \\
\hline devt & (16) & 0.84 & 0.24 & 0.00 & 1.00 \\
\hline
\end{tabular}

\section{Empirical Finding}

Table 2 provides the estimation of firm performance predicted by various director skills. Using panel data estimations, this research has also examined the impact of generalist or specialist CEOs/directors on variation in corporate performance and risk. Table 2(a) examines the effects of director education and director professionalism on corporate performance and risk. Table 2(b) shows the firm performance and risk estimation with the predictor of director skill experience and skill generality/specialty.

The statistic results in (a) reports that education and professional skills are associated with higher levels of firm performance and lower levels of firm risk except for the relationships between education skill and earning per share. Table 2(b) also shows a similar association for experience skill, firm performance, and firm risk. Further, Table 2(b) reports that managers with generalists' skills (higher Skills index score) perform better compared with the director with specialist properties in terms of firm performance and firm risk.

The empirical evidence has shown that executives and board members various skills could contribute to higher performance and lower risks. The result highlights the importance of director multidimensional skill for firm performance. This notion is consistent with previous research that discovered that director education (Saidu, 2019) and director experience (James, Wang, \& Xie, 2018) are associated with better firm performance. 
Table 2. Effect of skills on performance and risk.

(a)

\begin{tabular}{ccccccccc}
\hline & ROE & EPS & ZSCR & $\sigma(R O E)$ & ROE & EPS & ZSCR & $\sigma(R O E)$ \\
\hline & $0.21^{\star *}$ & 0.05 & $0.15^{\star * *}$ & -0.46 & & &
\end{tabular}

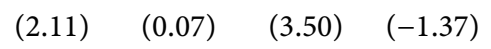

PRO

$0.19^{* * *} \quad 0.13^{\star} \quad 0.01^{\star}-0.96^{\star *}$

$\begin{array}{ccccccccc} & & & & & (3.39) & (2.26) & (2.16) & (-2.80) \\ \text { fsize } & 0.24 & 0.11 & 0.23 & 0.64 & 0.24 & 0.10 & 0.23 & 1.13 \\ & (1.86) & (0.45) & (1.87) & (0.66) & (1.98) & (0.39) & (1.84) & (1.14) \\ & 0.94^{*} & -0.97 & 0.49^{*} & -8.38 & 0.63^{* *} & -1.05 & 0.41^{\star} & -9.55 \\ \operatorname{lv} v & (2.18) & (-0.85) & (2.30) & (-1.89) & (2.97) & (-0.88) & (2.06) & (-1.85)\end{array}$

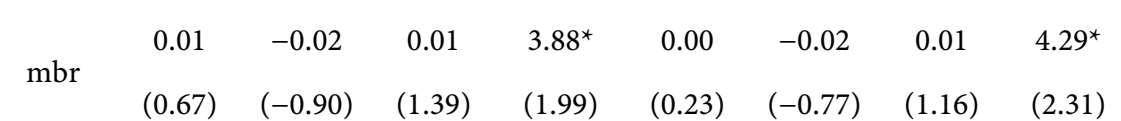

$\begin{array}{llllllllll} & -0.84 & 2.67^{\star} & -0.42 & 7.47^{\star} & -1.24 & 2.78^{*} & -0.44 & 8.29^{*}\end{array}$

$\begin{array}{lllllllll}\text { tgbl } & (-1.30) & (2.02) & (-1.16) & (2.74) & (-1.97) & (2.28) & (-1.22) & (2.69)\end{array}$

$\begin{array}{lllllllll}\text { prft } & 0.01 & -0.02 & 0.01 & 0.07 & 0.02 & -0.02 & 0.01 & 0.06\end{array}$

$\begin{array}{lllllllll}\text { prft } & (1.70) & (-0.89) & (1.20) & (1.03) & (1.96) & (-0.94) & (1.23) & (0.99)\end{array}$

$\begin{array}{llllllllll} & -3.31^{* * *} & -15.40 & 0.41 & 2.12^{*} & -3.62^{* * *} & -15.33 & 0.80 & 7.73^{* *}\end{array}$

$\begin{array}{lllllllll}\text { bsize } & (-4.49) & (-1.86) & (0.36) & (2.12) & (-1.66) & (-1.88) & (0.71) & \text { (3.47) }\end{array}$

$\begin{array}{lllllllll}\text { dual } & 0.17 & -0.54 & 0.04 & 0.04 & 0.23 & -0.56 & 0.07 & -0.28\end{array}$

$\begin{array}{llllllll}(1.06) & (-1.24) & (0.55) & (0.07) & (1.45) & (-1.26) & (0.91) & (-0.46)\end{array}$

$\begin{array}{llllllllll} & 0.87 & 2.02 & 0.84^{*} & -0.52 & 1.02 & 1.98 & 0.90^{*} & -1.27\end{array}$

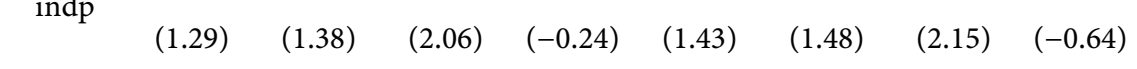

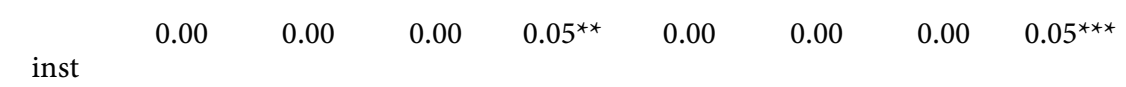

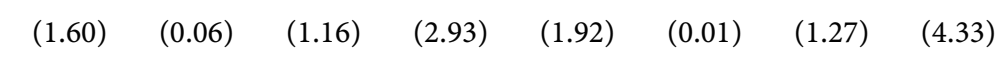

$\begin{array}{lllllllll} & 0.10 & -0.20^{*} & -0.05 & -1.52 & 0.06 & -0.19^{*} & -0.07 & -1.35\end{array}$

$\begin{array}{llllllllll}\text { mngr } & (0.62) & (-2.41) & (-0.57) & (-1.23) & (0.38) & (-2.39) & (-0.74) & (-1.24)\end{array}$

$\begin{array}{lllllllll} & 0.48 & 1.49^{* *} & 0.39^{*} & -1.49 & 0.49 & 1.49^{* *} & 0.39^{*} & -1.25\end{array}$

$\begin{array}{lllllllll}\text { blck } & (1.46) \quad(2.83) & (2.15) & (-1.36) & (1.40) & (2.86) & (2.09) & (-1.71)\end{array}$

$\begin{array}{lllllllll} & -0.05 & -0.44 & -0.25 & 4.66^{*} & -0.13 & -0.42 & -0.28 & 5.80^{* *}\end{array}$

$\begin{array}{lllllllll}\text { devt } & (-0.09) & (-0.52) & (-0.84) & (2.55) & (-0.20) & (-0.53) & (-0.89) & (2.87)\end{array}$

$\begin{array}{cccccccccc} & & -11.04^{\star} & -27.55^{\star \star} & -16.72^{\star \star} & 3.12 & -12.94^{\star} & -26.22^{\star} & -16.72^{\star \star} & 4.09 \\ \text { constant } & (-2.41) & (-3.06) & (-3.30) & (0.30) & (-2.63) & (-2.44) & (-3.13) & (0.39)\end{array}$

$\begin{array}{lllllllll}N & 119 & 113 & 127 & 107 & 119 & 113 & 127 & 133\end{array}$

$\begin{array}{lllllllll}R 2 & 0.326 & 0.279 & 0.369 & 0.529 & 0.327 & 0.280 & 0.357 & 0.562\end{array}$ 
(b)

\begin{tabular}{|c|c|c|c|c|c|c|c|c|}
\hline & ROE & EPS & ZSCR & $\sigma(R O E)$ & ROE & EPS & ZSCR & $\sigma(R O E)$ \\
\hline \multirow{2}{*}{ EXP } & $0.33^{*}$ & -1.33 & 0.02 & $-4.07^{\star}$ & & & & \\
\hline & $(2.04)$ & $(-1.85)$ & $(0.12)$ & $(-2.50)$ & & & & \\
\hline \multirow{2}{*}{ GEN } & & & & & $0.54^{\star \star}$ & $2.39^{*}$ & 0.25 & $-0.76^{\star \star}$ \\
\hline & & & & & $(3.56)$ & (2.08) & $(0.92)$ & $(-2.75)$ \\
\hline \multirow{2}{*}{ fsize } & 0.21 & 0.25 & 0.23 & 1.03 & 0.22 & 0.16 & 0.22 & 0.82 \\
\hline & $(1.71)$ & $(0.94)$ & $(1.75)$ & $(0.82)$ & $(1.70)$ & $(0.59)$ & (1.79) & $(0.89)$ \\
\hline \multirow{2}{*}{ lvrg } & $0.69^{* *}$ & -1.11 & $0.40^{*}$ & $-11.38^{*}$ & $0.85^{\star}$ & -0.81 & 0.42 & $-8.97^{\star}$ \\
\hline & $(2.74)$ & $(-0.98)$ & $(2.08)$ & $(-2.29)$ & $(2.38)$ & $(-0.65)$ & (1.96) & $(-1.99)$ \\
\hline \multirow{2}{*}{$\mathrm{mbr}$} & 0.00 & -0.02 & 0.01 & $4.81^{\star}$ & 0.01 & -0.02 & 0.01 & $4.14^{\star}$ \\
\hline & $(0.47)$ & $(-0.88)$ & $(1.20)$ & (1.97) & $(0.53)$ & $(-0.99)$ & $(1.22)$ & $(2.19)$ \\
\hline \multirow{2}{*}{ tgbl } & -1.04 & 2.25 & -0.42 & $9.35^{\star}$ & -1.06 & $2.69^{\star}$ & -0.45 & $8.05^{\star}$ \\
\hline & $(-1.74)$ & $(1.73)$ & $(-1.21)$ & $(2.36)$ & $(-1.72)$ & $(2.22)$ & $(-1.32)$ & $(2.77)$ \\
\hline \multirow{2}{*}{ prft } & 0.01 & -0.01 & 0.01 & 0.08 & 0.02 & -0.03 & 0.01 & 0.06 \\
\hline & (1.61) & $(-0.50)$ & $(1.25)$ & (1.01) & (1.91) & $(-1.20)$ & (1.41) & (1.09) \\
\hline \multirow{2}{*}{ bsize } & $-3.52^{\star}$ & -14.33 & 0.76 & $8.41^{\star}$ & $-2.60^{\star * *}$ & -9.04 & 0.27 & $5.69^{* *}$ \\
\hline & $(-2.60)$ & $(-1.83)$ & $(0.68)$ & $(2.49)$ & $(-4.15)$ & $(-1.00)$ & $(0.26)$ & $(3.32)$ \\
\hline \multirow{2}{*}{ dual } & 0.22 & -0.59 & 0.07 & -0.11 & 0.20 & -0.55 & 0.07 & -0.19 \\
\hline & $(1.46)$ & $(-1.34)$ & $(0.94)$ & $(-0.19)$ & $(1.30)$ & $(-1.28)$ & $(0.92)$ & $(-0.32)$ \\
\hline \multirow{2}{*}{ indp } & 1.02 & 1.78 & $0.90^{*}$ & -1.28 & 1.01 & 2.03 & $0.92^{*}$ & -0.94 \\
\hline & (1.55) & $(1.22)$ & $(2.13)$ & $(-0.59)$ & $(1.48)$ & $(1.56)$ & $(2.19)$ & $(-0.46)$ \\
\hline \multirow{2}{*}{ inst } & $0.00^{*}$ & -0.00 & 0.00 & $0.06^{\star * *}$ & 0.00 & -0.00 & 0.00 & $0.05^{\star * *}$ \\
\hline & $(2.04)$ & $(-0.09)$ & $(1.24)$ & $(3.34)$ & $(1.73)$ & $(-0.10)$ & $(1.30)$ & $(3.43)$ \\
\hline \multirow{2}{*}{ mngr } & 0.07 & $-0.26^{\star}$ & -0.07 & -2.33 & 0.07 & $-0.14^{\star}$ & -0.07 & -1.35 \\
\hline & $(0.48)$ & $(-2.55)$ & $(-0.73)$ & $(-1.45)$ & $(0.47)$ & $(-2.30)$ & $(-0.80)$ & $(-1.30)$ \\
\hline \multirow{2}{*}{ blck } & 0.51 & $1.43^{*}$ & $0.40^{*}$ & -1.55 & 0.49 & $1.48^{* *}$ & $0.40^{*}$ & -1.07 \\
\hline & $(1.57)$ & $(2.61)$ & $(2.09)$ & $(-1.63)$ & (1.45) & $(2.82)$ & $(2.16)$ & $(-1.37)$ \\
\hline \multirow{2}{*}{ devt } & -0.20 & -0.05 & -0.29 & $7.73^{\star * *}$ & -0.10 & -0.46 & -0.29 & $4.96^{* *}$ \\
\hline & $(-0.34)$ & $(-0.06)$ & $(-0.90)$ & (3.99) & $(-0.17)$ & $(-0.59)$ & $(-0.96)$ & $(2.70)$ \\
\hline \multirow{2}{*}{ constant } & -0.62 & $-2.25^{\star *}$ & -0.49 & 0.85 & -0.59 & $-2.27^{\star \star}$ & -0.49 & 0.17 \\
\hline & $(-1.52)$ & $(-3.15)$ & $(-1.88)$ & $(0.52)$ & $(-1.39)$ & $(-3.40)$ & $(-1.93)$ & $(0.15)$ \\
\hline$N$ & 119 & 113 & 127 & 133 & 119 & 113 & 127 & 130 \\
\hline$R 2$ & 0.330 & 0.320 & 0.357 & 0.601 & 0.326 & 0.310 & 0.362 & 0.551 \\
\hline
\end{tabular}

Notes: The models are estimated by OLS with robust standard errors clustered at the level of acquirer banks. $t$-statistics are reported in parentheses. Symbols ${ }^{* * *},{ }^{* *}$ and ${ }^{*}$ indicate significance at the $0.01,0.05$ and 0.1 levels, respectively. 
We also reported that generalist skill is significantly related to better firm performance and firm risk. This result is consistent with our research hypothesis. Therefore, we suspect that generality skill and experience provide the $\mathrm{CEO} /$ with various tools to leverage the firm performance. Moreover, the result aligned with Adams et al. (2005), who suggest that director generalists mainly offer higher skills to the firm in their tenure. However, this result did not match prior research suggesting that generalist skill directors will have more difficulty adapting to a problem or new environment (Li \& Patel, 2019).

\section{Conclusion}

This line of the literature shows that different skills provide variation for corporate outcomes. However, current empirical findings are inconsistent, and the question of whether the skill generality or skill specialty is beneficial to the firm is still controversial. Therefore, this study examines the benefit of multidimensional director skill (education, professionalism, experience) on firm performance and risk. In addition, this study inspects the contribution of skill generality or skill specialty in explaining firm performance and firm risk.

Given the policy reforms imposed by 2006 for the regulation of disclosure on individual skills of each director and any nominee for a board member, the data cover the period from 2006 to 2014 for Taiwan-listed non-financial firms. We find that executives and board members with higher educational backgrounds, greater expertise, and experiences contribute to higher performance and lower risks. Further, the generalist director is associated with better firm performance and reduced firm risk. The result is aligned with Adams et al. (2005) that suggest that director generalists mainly offer higher skills to the firm in their tenure. However, this result did not match Li and Patel (2019) that suggested that generalist skill directors will have more difficulty in their adaptation process in handling a problem or new environment.

This research contributes to the literature in the following ways. First, instead of focusing on a single criterion, this study includes multiple criteria of individual skills: education background, professional expertise, and prior experience. Second, this research helps to examine the debate over the value of generalists versus specialists as $\mathrm{CEO}$ /directors.

\section{Conflicts of Interest}

The authors declare no conflicts of interest regarding the publication of this paper.

\section{References}

Adams, R. B., Akyol, A. C., \& Verwijmeren, P. (2018). Director Skill Sets. Journal of Financial Economics, 130, 641-662. https://doi.org/10.1016/j.jfineco.2018.04.010

Adams, R. B., Almeida, H., \& Ferreira, D. (2005). Powerful CEOs and Their Impact on Corporate Performance. The Review of Financial Studies, 18, 1403-1432.

https://doi.org/10.1093/rfs/hhi030 
Akyol, A. C., \& Verwijmeren, P. (2013). Human Capital Costs, Firm Leverage, and Unemployment Rates. Journal of Financial Intermediation, 22, 464-481. https://doi.org/10.1016/j.jfi.2013.04.003

Almeida, H., Hsu, P. H., \& Li, D. (2013, April 1). Less is More: Financial Constraints and Innovative Efficiency. https://ssrn.com/abstract=1831786 http://dx.doi.org/10.2139/ssrn.1831786

Bertrand, M., \& Schoar, A. (2003). Managing with Style: The Effect of Managers on Firm Policies. The Quarterly Journal of Economics, 118, 1169-1208. https://doi.org/10.1162/003355303322552775

Brockman, P., Lee, H. S., \& Salas, J. M. (2012, March 15). CEO Compensation and the Role of In-House Experience. https://ssrn.com/abstract=2024398 https://doi.org/10.2139/ssrn.2024398

Coles, J. L., Daniel, N. D., \& Naveen, L. (2008). Boards: Does One Size Fit All? Journal of Financial Economics, 87, 329-356. https://doi.org/10.1016/j.jfineco.2006.08.008

Custódio, C., \& Metzger, D. (2013). How Do CEOs Matter? The Effect of Industry Expertise on Acquisition Returns. The Review of Financial Studies, 26, 2008-2047. https://doi.org/10.1093/rfs/hht032

Custódio, C., Ferreira, M. A., \& Matos, P. (2013). Generalists versus Specialists: Lifetime Work Experience and Chief Executive Officer Pay. Journal of Financial Economics, 108, 471-492. https://doi.org/10.1016/j.jfineco.2013.01.001

Dah, M. A., Frye, M. B., \& Hurst, M. (2014). Board Changes and CEO Turnover: The Unanticipated Effects of the Sarbanes-Oxley Act. Journal of Banking \& Finance, 41, 97-108. https://doi.org/10.1016/j.jbankfin.2014.01.006

Dass, N. et al. (2014). Board Expertise: Do Directors from Related Industries Help Bridge the Information Gap? The Review of Financial Studies, 27, 1533-1592. https://doi.org/10.1093/rfs/hht071

Drobetz, W. et al. (2018). Industry Expert Directors. Journal of Banking and Finance, 92, 195-215. https://doi.org/10.1016/j.jbankfin.2018.04.019

Fahlenbrach, R., Low, A., \& Stulz, R. M. (2010). Why Do Firms Appoint CEOs as Outside Directors? Journal of Financial Economics, 97, 12-32.

https://doi.org/10.1016/j.jfineco.2010.01.003

Fahlenbrach, R., Minton, B. A., \& Pan, C. H. (2011). Former CEO Directors: Lingering CEOs or Valuable Resources? The Review of Financial Studies, 24, 3486-3518. https://doi.org/10.1093/rfs/hhr056

Falato, A., Li, D., \& Milbourn, T. (2010). To Each According to His Ability? The Returns to CEO Talent. Working Paper, Federal Reserve Board.

Faleye, O., Hoitash, R., \& Hoitash, U. (2017). Industry Expertise on Corporate Boards. Review of Quantitative Finance and Accounting, 50, 441-479. https://doi.org/10.1007/s11156-017-0635-z

Fich, E. M. (2005). Are Some Outside Directors Better than Others? Evidence from Director Appointments by Fortune 1000 Firms. Journal of Business, 78, 1943-1971. https://doi.org/10.1086/431448

Giannetti, M. (2011). Serial CEO Incentives and the Structure of Managerial Contracts. Journal of Financial Intermediation, 20, 633-662. https://doi.org/10.1016/j.jfi.2011.04.003

Graham, J. R., Li, S., \& Qiu, J. (2012). Managerial Attributes and Executive Compensation. The Review of Financial Studies, 25, 144-186. https://doi.org/10.1093/rfs/hhr076

Groysberg, B., McLean, A. N., \& Nohria, N. (2006). Are Leaders Portable? May. 
https://hbr.org/2006/05/are-leaders-portable

Hambrick, D. C., \& Mason, P. A. (1984). Upper Echelons: The Organization as a Reflection of Its Top Managers. The Academy of Management Review, 9, 193-206. https://doi.org/10.2307/258434

James, H. L., Wang, H., \& Xie, Y. (2018). Busy Directors and Firm Performance: Does Firm Location Matter? The North American Journal of Economics and Finance, 45, 1-37. https://doi.org/10.1016/j.najef.2018.01.010

Kang, S., Kim, E. H., \& Lu, Y. (2018). Does Independent Directors CEO Experience Matter? Review of Finance, 22, 905-949. https://doi.org/10.1093/rof/rfx023

Kaplan, S. N., Klebanov, M. M., \& Sorensen, M. (2012). Which CEO Characteristics and Abilities Matter? The Journal of Finance, 67, 973-1007. https://doi.org/10.1111/j.1540-6261.2012.01739.x

Kim, E. H., \& Lu, Y. (2017). Executive Suite Independence: Is It Related to Board Independence? Informs, 64, 1015-1033. https://doi.org/10.1287/mnsc.2016.2603

Landier, A. et al. (2013). Bottom-Up Corporate Governance. Review of Finance, 17, 161-201. https://doi.org/10.1093/rof/rfs020

Lazear, E. P. (2012). Leadership: A Personnel Economics Approach. Labour Economics, 19, 92-101. https://doi.org/10.1016/j.labeco.2011.08.005

Li, M., \& Patel, P. C. (2019). Jack of All, Master of All? CEO Generalist Experience and Firm Performance. The Leadership Quarterly, 30, 320-334. https://doi.org/10.1016/j.leaqua.2018.08.006

Manso, G. (2011). Motivating Innovation. The Journal of Finance, 66, 1823-1860. https://doi.org/10.1111/j.1540-6261.2011.01688.x

Martijn Cremers, K. J., \& Grinstein, Y. (2014). Does the Market for CEO Talent Explain Controversial CEO Pay Practices? Review of Finance, 18, 921-960. https://doi.org/10.1093/rof/rft024

Mobbs, S. (2013). CEOs under Fire: The Effects of Competition from Inside Directors on Forced CEO Turnover and CEO Compensation. Journal of Financial and Quantitative Analysis, 48, 669-698. https://doi.org/10.1017/S0022109013000318

Mobbs, S., \& Raheja, C. G. (2012). Internal Managerial Promotions: Insider Incentives and CEO Succession. Journal of Corporate Finance, 18, 1337-1353. https://doi.org/10.1016/j.jcorpfin.2012.09.001

Murphy, K. J., Zabojnik, J., \& Zábojník, J. (2006). Managerial Capital and the Market for CEOs. https://doi.org/10.2139/ssrn.984376

Saidu, S. (2019). CEO Characteristics and Firm Performance: Focus on Origin, Education and Ownership. Journal of Global Entrepreneurship Research, 9, Article No. 29. https://doi.org/10.1186/s40497-019-0153-7

Tate, G., \& Yang, L. (2015). Female Leadership and Gender Equity: Evidence from Plant Closure. Journal of Financial Economics, 117, 77-97. https://doi.org/10.1016/j.jfineco.2014.01.004

White, J. T. et al. (2014). Appointments of Academic Directors. Journal of Corporate Finance, 28, 135-151. https://doi.org/10.1016/j.jcorpfin.2013.12.007 


\section{Appendix}

Table A1. Measurement for Director Skills and Control Variable.

\begin{tabular}{cc}
\hline Variable Name & Definition \\
\hline Skill & \\
\hline Education &
\end{tabular}

Education

BA

The dummy variable that equals 1 if the CEO's highest educational degree is bachelor's degree, and zero otherwise.

MBA

The dummy variable that equals 1 if the CEO's highest educational degree is master's degree, and zero otherwise.

$\mathrm{PhD} \quad$ The dummy variable that equals 1 if the CEO's highest educational degree is $\mathrm{PhD}$, and zero otherwise.

\section{Professional}

Finance

The dummy variable that equals 1 if the $\mathrm{CEO} /$ director has

\begin{tabular}{|c|c|}
\hline Finance & $\begin{array}{l}\text { banking, economics, or finance expertise in his or her background, } \\
\text { and zero otherwise. }\end{array}$ \\
\hline Accounting & $\begin{array}{l}\text { The dummy variable that equals } 1 \text { if the CEO/director has } \\
\text { accounting or auditing expertise in his or her background, } \\
\text { and zero otherwise. }\end{array}$ \\
\hline Governance & $\begin{array}{l}\text { The dummy variable that equals } 1 \text { if the CEO/director has } \\
\text { corporate governance expertise in his or her background, } \\
\text { and zero otherwise. }\end{array}$ \\
\hline Compensation & $\begin{array}{l}\text { The dummy variable that equals } 1 \text { if the CEO/director has } \\
\text { compensation and incentives expertise in his or her background, } \\
\text { and zero otherwise. }\end{array}$ \\
\hline Legal & $\begin{array}{l}\text { The dummy variable that equals } 1 \text { if the CEO/director has } \\
\text { governmental, policy, regulatory, or legal expertise in his or } \\
\text { background, and zero otherwise. }\end{array}$ \\
\hline International & $\begin{array}{l}\text { The dummy variable that equals } 1 \text { if the CEO/director has } \\
\text { international affair expertise in his background and zero otherwise. }\end{array}$ \\
\hline Leadership & $\begin{array}{l}\text { The dummy variable that equals } 1 \text { if the CEO/director is someone } \\
\text { that has leadership, management, or communications expertise } \\
\text { in his or her background, and zero otherwise. }\end{array}$ \\
\hline $\mathrm{R} \& \mathrm{D}$ & $\begin{array}{l}\text { The dummy variable that equals } 1 \text { if the } \mathrm{CEO} / \text { director has } \\
\text { engineering, scientific, technology, or R \& D expertise in his } \\
\text { or her background, and zero otherwise. }\end{array}$ \\
\hline Manufacturing & $\begin{array}{l}\text { The dummy variable that equals } 1 \text { if the } \mathrm{CEO} / \text { director has } \\
\text { manufacturing expertise in his or her background, } \\
\text { and zero otherwise. }\end{array}$ \\
\hline Marketing & $\begin{array}{l}\text { The dummy variable that equals } 1 \text { if the } \mathrm{CEO} / \text { director has } \\
\text { marketing or sales expertise in his or her background, } \\
\text { and zero otherwise. }\end{array}$ \\
\hline Risk & $\begin{array}{l}\text { The dummy variable that equals } 1 \text { if the CEO/director has risk } \\
\text { management expertise in his or her background, and zero otherwise. }\end{array}$ \\
\hline
\end{tabular}




\section{Continued}

\begin{tabular}{|c|c|}
\hline Strategies & $\begin{array}{l}\text { The dummy variable that equals } 1 \text { if the CEO/director has strategy } \\
\text { planning expertise in his or her background, and zero otherwise. }\end{array}$ \\
\hline Sustainability & $\begin{array}{l}\text { The dummy variable that equals } 1 \text { if the } \mathrm{CEO} / \text { director has } \\
\text { environmental or sustainability issues expertise in his or } \\
\text { her background, and zero otherwise. }\end{array}$ \\
\hline \multicolumn{2}{|l|}{ Experience } \\
\hline Academic & $\begin{array}{l}\text { The dummy variable that equals } 1 \text { if the CEO/director is from } \\
\text { academia, and zero otherwise. }\end{array}$ \\
\hline Firm & $\begin{array}{l}\text { The dummy variable that equals } 1 \text { if the CEO/director has } \\
\text { worked for other companies, and zero otherwise. }\end{array}$ \\
\hline Industry & $\begin{array}{l}\text { The dummy variable that equals } 1 \text { if the } \mathrm{CEO} / \text { director has } \\
\text { worked in other industries, and zero otherwise. }\end{array}$ \\
\hline Experience & $\begin{array}{l}\text { The dummy variable that equals } 1 \text { if the CEO/director had held } \\
\text { CEO position at another company, and zero otherwise. }\end{array}$ \\
\hline Conglomerate & $\begin{array}{l}\text { The dummy variable that equals } 1 \text { if the CEO/director had } \\
\text { worked for multisegmented company, and zero otherwise. }\end{array}$ \\
\hline Recession & $\begin{array}{l}\text { The dummy variable that equals } 1 \text { if the } \mathrm{CEO} / \text { director } \\
\text { experienced a recession year, defined by National Bureau of } \\
\text { Economics Research, after his or her first academic-degree } \\
\text { graduation, and zero otherwise. }\end{array}$ \\
\hline OutsideBoard & $\begin{array}{l}\text { The dummy variable that equals } 1 \text { if the } \mathrm{CEO} / \text { director has } \\
\text { outside board experience, and zero otherwise. }\end{array}$ \\
\hline OutsideExecutive & $\begin{array}{l}\text { The dummy variable that equals } 1 \text { if the } \mathrm{CEO} / \text { director was } \\
\text { an executive of another company, and zero otherwise. }\end{array}$ \\
\hline Entrepreneurial & $\begin{array}{l}\text { The dummy variable that equals } 1 \text { if the } \mathrm{CEO} / \text { director has } \\
\text { entrepreneurial experience, and zero otherwise. }\end{array}$ \\
\hline \multicolumn{2}{|l|}{ Control } \\
\hline \multicolumn{2}{|l|}{ Firm } \\
\hline \multicolumn{2}{|l|}{ Characteristic } \\
\hline fsize & firm size is the natural logarithm of total assets. \\
\hline lvrg & $\begin{array}{l}\text { leverage is ratio of total debts including long-term debt and } \\
\text { short-term debt to total assets. }\end{array}$ \\
\hline $\operatorname{tgbl}$ & $\begin{array}{l}\text { tangibility is the ratio of property, plant, and equipment plus } \\
\text { inventories to total assets. }\end{array}$ \\
\hline prft & profitability is the ratio of net income to total sales. \\
\hline mbr & market to book ratio is the ratio of market value to total assets. \\
\hline \multicolumn{2}{|l|}{ Governance } \\
\hline \multicolumn{2}{|l|}{ Characteristic } \\
\hline bsize & board size is the natural logarithm of number of board directors. \\
\hline dual & $\begin{array}{l}\text { duality is a dummy variable that equals } 1 \text { if the CEO fulfills } \\
\text { both the function as CEO and chairman of the board of directors, } \\
\text { and } 0 \text { otherwise. }\end{array}$ \\
\hline
\end{tabular}




\section{Continued}

\begin{tabular}{|c|c|}
\hline indp & $\begin{array}{l}\text { independence is a dummy variable that equals } 1 \text { if firms have } \\
\text { independent board in their board, and } 0 \text { otherwise. }\end{array}$ \\
\hline inst & $\begin{array}{l}\text { institutional shareholding is the ratio of the number of shares held } \\
\text { by institutional investors to the number of shares outstanding. }\end{array}$ \\
\hline mngr & $\begin{array}{l}\text { managerial shareholding is the ratio of the number of shares held } \\
\text { by executives to the number of shares outstanding. }\end{array}$ \\
\hline blck & $\begin{array}{l}\text { blockholder shareholding is the ratio of the number of shares held } \\
\text { by } 10 \text { largest shareholders to the number of shares outstanding. }\end{array}$ \\
\hline devt & deviation ratio is the ratio of voting rights to cash-flow rights. \\
\hline
\end{tabular}

